\title{
KONTRIBUSI KEMAMPUAN KALKULUS I DAN KALKULUS II TERHADAP HASIL BELAJAR MATA KULIAH ANALISIS VEKTOR
}

\author{
Sri Rejeki
}

\begin{abstract}
Abstrak
Tujuan dari penelitian ini adalah untuk: (1) menguji signifikansi kontribusi kemampuan Kalkulus I terhadap hasil belajar mata kuliah Analisis Vektor, (2) menguji signifikansi kontribusi kemampuan Kalkulus II terhadap hasil belajar mata kuliah Analisis Vektor, (3) menguji signifikansi kontribusi kemampuan Kalkulus I dan Kalkulus II terhadap hasil belajar mata kuliah Analisis Vektor. Penelitian ini merupakan penelitian kuantitatif assosiatif dengan populasi seluruh mahasiswa semester tiga Program Studi Pendidikan Matematika, Universitas Muhammadiyah Surakarta Tahun Akademik 2014/2015. Sampel dari penelitian ini adalah 25 mahasiswa yang diperoleh dengan teknik sampling kuota. Metode tes dan dokumentasi digunakan untuk mengumpulkan data penelitian. Data tersebut dianalisis menggunakan uji regresi linier ganda dengan tingkat signifikansi 5\% dan dilakukan dengan menggunakan software SPSS. Berdasarkan analisis data tersebut, dapat disimpulkan bahwa: (1) tidak terdapat kontribusi yang signifikan dari kemampuan Kalkulus I terhadap hasil belajar Analisis Vektor, (2) terdapat kontribusi yang signifikan dari kemampuan Kalkulus II terhadap hasil belajar Analisis Vektor, (3) terdapat kontribusi yang signifikan dari kemampuan Kalkulus I dan Kalkulus II terhadap hasil belajar Analisis Vektor.
\end{abstract}

Kata Kunci: analisis vektor, kalkulus I, kalkulus II.

\section{Pendahuluan}

Analisis Vektor atau yang juga dikenal dengan Kalkulus Vektor merupakan salah satu mata kuliah yang harus ditempuh oleh mahasiswa di Program Studi Matematika maupun Pendidikan Matematika. Sebelum menempuh mata kuliah ini, terlebih dahulu mahasiswa harus menempuh mata kuliah Kalkulus I dan Kalkulus II yang merupakan mata kuliah prasyarat dari mata kuliah Analisis Vektor. Dua materi penting yang 
Sri Rejeki

menjadikan alasan Kalkulus I dan Kalkulus II sebagai mata kuliah prasyarat dari mata kuliah Analisis Vektor adalah materi differensial pada Kalkulus I dan integral pada Kalkulus II. Kedua materi tersebut, pada mata kuliah Analisis Vektor diaplikasikan pada masalah differensiasi dan integrasi vektor.

Secara matematis Analisis Vektor adalah salah satu cabang ilmu yang mempelajari analisis riil dari vektor dalam dua dimensi atau lebih. Analisis vektor melingkupi operasi vektor dan skalar, medan vektor dan medan skalar, diferensiasi dan integrasi vektor, serta teorema-teorema yang terkait dengan vektor dan melibatkan konsep-konsep differensial dan integral (Varberg, Purcell, dan Rigdon, 2007; Stewart, 2012). Cabang ilmu ini lebih banyak digunakan oleh insinyur dan fisikawan karena mencakup teknik-teknik dalam memecahkan masalah yang berkaitan dengan vektor. Akan tetapi, penting juga bagi matematikawan untuk menguasai konsepkonsep di dalam cabang ilmu ini.

Sementara itu Kalkulus adalah cabang ilmu matematika yang mencakup limit, differensial, deret tak terhingga, dan integral. Menurut Kamus Besar Bahasa Indonesia (2015), kalkulus adalah bagian matematika yg terutama melibatkan pengertian dan penggunaan diferensial dan integral fungsi serta konsep yg berkaitan. Kemudian, lebih lanjut disebutkan bahwa differensial adalah analisis matematis tentang ketergantungan laju perubahan fungsi dengan perubahan dalam variabel fungsi dan integral adalah analisis matematis tentang teknik penemuan ungkapan dan evaluasi fungsi integral, khususnya untuk kalkulasi luas, panjang, lengkung, volume, dan nomor serta penyelesaian persamaan diferensial sederhana.

Dalam mempelajari Kalkulus, pada umumnya dibagi menjadi Kalkulus I dan Kalkulus II. Kalkulus I, yang juga dikenal dengan Kalkulus Differensial mempelajari tentang limit, differensial, dan aplikasi differensial (Hw, 2009). Kalkulus II, yang juga dikenal dengan Kalkulus Integral mempelajari tentang integral tak tentu, integral tertentu, dan penggunaan integral tertentu (Hw, 2003). Teknik-teknik dan konsep-konsep differensial 
Kontribusi Kemampuan Kalkulus I dan Kalkulus II terhadap Hasil Belajar Mata Kuliah Analisis Vektor

dan integral inilah yang nantinya akan diperlukan ketika mempelajari materi differensiasi dan integrasi vektor pada mata kuliah Analisis Vektor.

Berdasarkan Kurikulum pada Program studi Pendidikan Matematika FKIP UMS, mata kuliah Analisis Vektor dapat ditempuh pada semester gasal, khususnya tersaji untuk mahasiswa semester III. Sementara itu, Kalkulus I dan Kalkulus II, masing-masing dapat ditempuh pada semester gasal dan semester genap, khususnya tersaji untuk mahasiswa semester I dan semester II.

Dari hasil observasi di kelas, pada pembelajaran Analisis Vektor, mahasiswa cenderung mengalami kesulitan dalam memecahkan masalah, terutama pada permasalahan yang terkait dengan differensiasi dan integrasi vektor. Kesulitan ini dapat berdampak negatif pada pencapaian hasil belajar mahasiswa pada mata kuliah ini. Sebagai mata kuliah prasyarat, dimungkinkan kemampuan Kalkulus I dan Kalkulus II memberikan kontribusi terhadap hasil belajar mahasiswa. Terlebih, berdasarkan hasil observasi, kesulitan siswa disebabkan karena mahasiswa melupakan konsepkonsep yang telah dipelajari pada Kalkulus I dan Kalkulus II.

Penguasaan konsep-konsep yang menjadi kemampuan prasyarat dari suatu mata kuliah merupakan faktor penting yang mempengaruhi hasil belajar siswa atau mahasiswa (Ari, 2014). Hal senada menjadi kesimpulan dari penelitian yang dilakukan oleh Paris dan Assidiqi (2012) bahwa Kalkulus A berpengaruh nyata terhadap Kalkulus B, Kalkulus A berpengaruh nyata terhadap Kalkulus Lanjutan dan Persamaan Differensial, Kalkulus B berpengaruh nyata terhadap Kalkulus Lanjutan dan Persamaan Differensial, dan Kalkulus Lanjutan tidak berpengruh nyata terhadap Persamaan Differensial. Dalam hal ini, Kalkulus A (Kalkulus I), Kalkulus B (Kalkulus II), dan Kalkulus Lanjutan merupakan mata kuliah prasyarat dari Pesamaan Differensial.

Berdasarkan uraian di atas, penelitian ini bertujuan untuk: (1) menguji signifikansi kontribusi kemampuan Kalkulus I terhadap hasil belajar mata kuliah Analisis Vektor, (2) menguji signifikansi kontribusi kemampuan 
Kalkulus II terhadap hasil belajar mata kuliah Analisis Vektor, (3) menguji signifikansi kontribusi kemampuan Kalkulus I dan Kalkulus II terhadap hasil belajar mata kuliah Analisis Vektor.

\section{Metode Penelitian}

Jenis penelitian ini merupakan penelitian kuantitatif yaitu penelitian yang melibatkan perhitungan atau angka atau kuantitas (Maryadi, dkk, 2011). Selain itu, berdasarkan tujuannya penelitian ini termasuk penelitian asosiatif yaitu penelitian yang bertujuan untuk mengetahui hubungan antara dua variabel atau lebih (Sugiono, 2009). Hubungan tersebut bisa berbentuk hubungan korelasional, sumbangan atau kontribusi satu variabel terhadap variabel lainnya ataupun hubungan sebab akibat (Sutama, 2012: 40). Fokus penelitian ini adalah untuk mengetahui kontribusi dua variabel bebas terhadap satu variabel terikat. Variabel bebas dalam penelitian ini adalah kemampuan Kalkulus I dan Kalkulus II dan variabel terikatnya adalah hasil belajar mata kuliah Analisis Vektor.

Penelitian ini dilakukan di Program Studi Pendidikan Matematika Universitas Muhammadiyah Surakarta yang beralamat di JL. A. Yani Tromol Pos 1, Pabelan, Kartasura, Sukoharjo, Jawa Tengah. Populasi penelitian ini adalah seluruh mahasiswa Pendidikan Matematika semester III Universitas Muhammadiyah Surakarta tahun akademik 2014/2015 dengan 25 mahasiswa sebagai sampel penelitian. Teknik pengambilan sampel menggunakan teknik sampling kuota. Metode pengumpulan data dalam penelitian ini menggunakan metode tes dan dokumentasi. Metode tes digunakan untuk memperoleh nilai hasil belajar mata kuliah Analisis Vektor yang dilakukan dengan memberikan tes uraian dan metode dokumentasi digunakan untuk memperoleh nilai kemampuan Kalkulus I dan Kalkulus II yang diperoleh dari dokumen nilai akhir mahasiswa pada semester I (Kalkulus I) dan semester II (Kalkulus II).

Teknik analisis data menggunakan uji regresi linier ganda yang sebelumnya dilakukan uji prasyarat analisis regresi linier ganda yaitu uji 
Kontribusi Kemampuan Kalkulus I dan Kalkulus II terhadap Hasil Belajar Mata Kuliah Analisis Vektor

normalitas, uji linieritas, uji multikolinieritas, uji autokorelasi, uji heteroskedastisitas (Sufren, 2014). Seluruh analisis statistik dilakukan dengan menggunakan software SPSS.

\section{Hasil dan Pembahasan}

Data kemampuan Kalkulus I, Kalkulus II, dan hasil belajar mahasiswa pada mata kuliah Analisis Vektor dapat disajikan dalam tabel dibawah ini.

Tabel 1. Data Kemampuan Kalkulus I

\begin{tabular}{|l|c|}
\hline Data & $\begin{array}{c}\text { Kemampuan } \\
\text { Kalkulus I }\end{array}$ \\
\hline Nilai tertinggi & 91 \\
\hline Nilai terendah & 41,89 \\
\hline Mean & 63,8628 \\
\hline Modus & 54,75 \\
\hline Median & 64,75 \\
\hline Standar deviasi & 12,11140 \\
\hline
\end{tabular}

Tabel 2. Data Kemampuan Kalkulus I

\begin{tabular}{|l|c|}
\hline \multicolumn{1}{|c|}{ Data } & \multicolumn{1}{c|}{$\begin{array}{c}\text { Kemampuan } \\
\text { Kalkulus II }\end{array}$} \\
\hline Nilai tertinggi & 90,64 \\
\hline Nilai terendah & 35,29 \\
\hline Mean & 59,2500 \\
\hline Modus & 53,39 \\
\hline Median & 55,64 \\
\hline Standar deviasi & 14,07940 \\
\hline
\end{tabular}

Tabel 3. Data Hasil belajar mata kuliah Analisis Vektor

\begin{tabular}{|l|c|}
\hline Data & $\begin{array}{c}\text { Hasil belajar mata } \\
\text { kuliah Analisis } \\
\text { Vektor }\end{array}$ \\
\hline Nilai tertinggi & 91,35 \\
\hline Nilai terendah & 53,40 \\
\hline Mean & 69,0344 \\
\hline Modus & 73,49 \\
\hline Median & 66,44 \\
\hline Standar deviasi & 11,79594 \\
\hline
\end{tabular}


Berdasarkan tabel-tabel di atas dapat diketahui bahwa nilai tertinggi pada hasil belajar mata kuliah Analisis Vektor lebih tinggi dibandingkan dengan nilai tertinggi pada kemampuan Kalkulus I dan kemampuan Kalkulus II dan nilai terendah hasil belajar mata kuliah Analisis Vektor juga lebih tinggi dibandingkan dengan nilai terendah pada kemampuan Kalkulus I dan kemampuan Kalkulus II. Hasil mean, modus dan median pada data hasil belajar mata kuliah Analisis Vektor pun lebih tinggi dibandingkan dengan mean, median, dan modus pada kemampuan Kalkulus I dan kemampuan Kalkulus II. Akan tetapi, standar deviasi pada hasil belajar mata kuliah Analisis Vektor lebih rendah dibandingkan dengan standar deviasi pada kemampuan Kalkulus I dan kemampuan Kalkulus II.

Berdasarkan data yang telah diperoleh, hasil uji normalitas dengan Kolmogorov-Smirnov menunjukkan bahwa variabel residu berdistribusi normal dan model regresi telah memenuhi asumsi normalitas. Uji linieritas memberikan hasil bahwa $X_{1}$ terhadap $Y$ (kemampuan kalkulus I terhadap hasil belajar mata kuliah Analisis Vektor) dan $X_{2}$ terhadap $Y$ (kemampuan Kalkulus II terhadap hasil belajar mata kuliah Analisis Vektor) masingmasing mempunyai hubungan linier secara signifikan. Hasil uji multikolinearitas dengan melihat nilai tolerance dan Variance Inflation Faktor (VIF) menunjukkan bahwa tidak terjadi korelasi di antara variabel bebas atau tidak terjadi masalah multikolinearitas. Uji autokorelasi dengan Durbin Watson SPSS memberikan kesimpulan bahwa tidak terdapat masalah autokorelasi. Kemudian, pada uji heteroskedastisitas dengan uji Glejser menunjukkan bahwa tidak terjadi masalah heteroskedastisitas. Hal ini juga didukung dengan hasil uji heteroskedastisitas dengan grafik scatter plot yang menunjukkan bahwa titik-titik menyebar dengan pola yang tidak jelas diatas dan dibawah angka nol pada sumbu $Y$.

Berdasarkan hasil dari uji prasyarat analisis tersebut, maka model regresi dapat digunakan. Dari data yang telah diperoleh didapat model regresi $\mathrm{Y}=21,579+0,630 \mathrm{X}_{1}+0,159 \mathrm{X}_{2}$. Selanjutnya dilakukan analisis dengan uji $\mathrm{t}$ dan uji $\mathrm{F}$ untuk mengetahui kontribusi kemampuan Kalkulus 1 
Kontribusi Kemampuan Kalkulus I dan Kalkulus II terhadap Hasil Belajar Mata Kuliah Analisis Vektor

terhadap hasil belajar mata kuliah Analisis Vektor, kontribusi kemampuan Kalkulus II terhadap hasil belajar mata kuliah Analisis Vektor, dan kontribusi kemampuan Kalkulus I dan Kalkulus II terhadap hasil belajar mata kuliah Analisis Vektor

1. Kontribusi kemampuan Kalkulus I terhadap hasil belajar mata kuliah Analisis Vektor

Berdasarkan hasil uji $\mathrm{t}$ atau uji parsial dengan $\alpha=0,05$ diperoleh hasil perhitungan nilai $t_{\text {hitung }}=1,165<t_{\text {tabel }}=1,1711$ dan nilai signifikansi sama dengan 0,05 sehingga $H_{0}$ diterima yang berarti bahwa tidak ada pengaruh yang signifikan dari kemampuan Kalkulus I terhadap hasil belajar mata kuliah Analisis Vektor. Artinya, kemampuan Kalkulus I tidak memberikan kontribusi yang signifikan pada hasil belajar mata kuliah Analisis Vektor.

Secara parsial, kemampuan Kalkulus I tidak memberikan kontribusi yang signifikan pada hasil belajar mata kuliah Analisis Vektor. Hal ini mungkin disebabkan karena konsep-konsep differensial yang relatif lebih sederhana dibandingkan dengan konsep-konsep integral. Dikarenakan konsep-konsep yang sederhana, mahasiswa secara mandiri dapat dengan mudah mengulang mempelajari konsep-konsep tersebut ketika menempuh mata kuliah Analisis Vektor.

Dalam penelitian ini, peneliti menggunakan kemampuan Kalkulus I sebagai salah satu variabel penelitian yang mempengaruhi hasil belajar mata kuliah Analisis Vektor. Pada penelitian ini dapat disimpulkan bahwa berapapun peningkatan nilai yang terjadi pada Kalkulus I, tidak memberikan kontribusi yang signifikan terhadap peningkatan hasil belajar mata kuliah Analisis Vektor.

2. Kontribusi kemampuan Kalkulus II terhadap hasil belajar mata kuliah Analisis Vektor

Berdasarkan hasil uji $\mathrm{t}$ atau uji parsial diperoleh hasil perhitungan nilai $t_{\text {hitung }}=5,374>t_{\text {tabel }}=1,1711$ dan nilai signifikansi kurang dari 0.05 sehingga $\mathrm{H}_{0}$ ditolak yang berarti bahwa ada pengaruh kemampuan Kalkulus 
II terhadap hasil belajar mata kuliah Analisis Vektor. Artinya kemampuan Kalkulus II memberikan kontribusi yang signifikan terhadap hasil belajar mata kuliah Analisis Vektor.

Secara parsial, kemampuan Kalkulus II memberikan kontribusi yang signifikan pada hasil belajar mata kuliah Persamaan Differensial. Hal ini mungkin disebabkan karena konsep-konsep integral yang relatif lebih kompleks dibandingkan dengan konsep-konsep differensial. Dikarenakan konsep-konsep yang kompleks, mahasiswa akan mengalami kesulitan untuk mengulang mempelajari konsep-konsep tersebut secara mandiri ketika menempuh mata kuliah Analisis Vektor.

Dalam penelitian ini, peneliti menggunakan kemampuan Kalkulus II sebagai salah satu variabel penelitian yang mempengaruhi hasil belajar mata kuliah Analisis Vektor. Pada penelitian ini dapat disimpulkan bahwa peningkatan nilai yang terjadi pada Kalkulus II memberikan kontribusi yang signifikan terhadap peningkatan hasil belajar mata kuliah Analisis Vektor.

\section{Kontribusi kemampuan Kalkulus I dan Kalkulus II terhadap hasil belajar} Analisis Vektor

Berdasarkan hasil uji $\mathrm{F}$ atau uji simultan diperoleh hasil perhitungan nilai $F_{\text {hitung }}=33,106>F_{\text {tabel }}=3,44$ dan nilai signifikansi kurang dari 0,05 sehingga $\mathrm{H}_{0}$ ditolak yang berarti bahwa ada pengaruh kemampuan Kalkulus I dan Kalkulus II terhadap hasil belajar mata kuliah Analisis Vektor. Artinya kemampuan Kalkulus I dan Kalkulus II memberikan kontribusi yang signifikan pada hasil belajar mata kuliah Analisis Vektor. Adapun nilai koefisien determinasi $\left(R^{2}\right)$ sebesar 0,751 yang berarti prosentase sumbangan yang diberikan oleh kemampuan Kalkulus I dan Kalkulus II terhadap hasil belajar mata kuliah Analisis Vektor adalah sebesar 75,1\%, sedangkan sisanya $24,9 \%$ dapat dipengaruhi oleh faktor lain di luar penelitian ini.

Hasil belajar mata kuliah Analisis Vektor adalah bukti keberhasilan yang dicapai setelah melalui proses belajar mengajar. Hasil belajar ini menunjukkan kecakapan mahasiswa dalam menguasai materi belajar Analisis Vektor yang dinyatakan dalam bentuk angka. Hasil penelitian 
Kontribusi Kemampuan Kalkulus I dan Kalkulus II terhadap Hasil Belajar Mata Kuliah Analisis Vektor

menunjukkan bahwa secara simultan kemampuan Kalkulus I dan Kalkulus II memberikan kontribusi yang signifikan pada hasil belajar mata kuliah Analisis Vektor. Artinya, peningkatan nilai yang terjadi pada Kalkulus I dan Kalkulus II memberikan kontribusi yang signifikan terhadap peningkatan hasil belajar mata kuliah Analisis Vektor. Hal ini mungkin disebabkan banyaknya penggunaan konsep-konsep differensial dan integral secara simultan pada teorema-teorema yang dipelajari dalam mata kuliah Analisis Vektor (Varberg, Purcell, dan Rigdon, 2007; Stewart, 2012).

Secara parsial tidak ada kontribusi yang signifikan dari kemampuan Kalkulus I dan ada kontribusi yang signifikan dari kemampuan Kalkulus II terhadap hasil belajar mata kuliah Analisis Vektor. Kemudian, secara simultan ada kontribusi yang signifikan dari kemampuan Kalkulus I dan Kalkulus II terhadap hasil belajar mata kuliah Analisis Vektor dengan prosentase sumbangan sebesar $75,1 \%$, sedangkan sisanya $24,9 \%$ dapat dipengaruhi oleh faktor lain di luar penelitian ini.

Dari hasil penelitian di atas, faktor kemampuan prasyarat secara simultan memberikan kontribusi yang cukup besar pada hasil belajar mata kuliah Analisis Vektor. Hal ini selaras dengan apa yang dikemukakan oleh Svinicki (1994) bahwa pengetahuan sebelumnya mempengaruhi bagaimana siswa/mahasiswa menerima informasi baru, mempengaruhi bagaimana siswa/mahasiswa mengorganisasi informasi baru, dan mempengaruhi bagaimana siswa/mahasiswa menghubungkan informasi-informasi baru. Oleh karena itu, kemampuan Kalkulus I dan Kalkulus II yang tinggi akan berdampak positif pada acara mahasiswa menerima, mengorganisasi, dan menghubungkan informasi-informasi baru dalam materi mata kuliah Analisis Vektor, yang akhirnya akan memberikan pengaruh positif terhadap hasil belajarnya.

Faktor-faktor lain yang mempengaruhi hasil belajar mata kuliah Analisis Vektor kemungkinan adalah faktor-faktor yang tidak diteliti dalam penelitian ini. Sugihartono, dkk. (2007) menyebutkan faktor-faktor yang mempengaruhi hasil belajar, sebagai berikut: (1) faktor internal adalah 
faktor yang ada dalam diri individu yang sedang belajar, meliputi faktor jasmaniah dan faktor psikologis dan (2) faktor eksternal adalah faktor yang ada di luar individu, meliputi faktor keluarga, faktor sekolah, dan faktor masyarakat. Sementara itu, menurut Djamarah (2008) faktor-faktor yang mempengaruhi proses dan hasil belajar dapat dibagi antara lain: (1) faktor lingkungan: lingkungan alami dan lingkungan sosial budaya, (2) instrumental: kurikulum, program, sarana dan fasilitas, guru, (3) fisiologis: kondisi fisiologis, kondisi pancaindra dan (4) psikologis: kecerdasan, bakat, motivasi, kemampuan kognitif.

Menurut Thomas F. Staton (dalam Samino, 2011) faktor-faktor psikologis yang menentukan hasil belajar yaitu motivasi, konsentrasi, reaksi, organisasi, pemahaman dan ulangan. Hal ini sesuai dengan penelitian Lestari (2010) tentang pengaruh motivasi dan cara belajar siswa terhadap hasil belajar matematika menyimpulkan bahwa terdapat pengaruh signifikan antara motivasi dan cara belajar siswa terhadap hasil belajar matematika. Selain itu Joseph dan Philias (2010) dalam Susilowati (2013) menyatakan bahwa fasilitas adalah penentu paling ampuh prestasi akademik.

Lebih lanjut, Susilowati (2013) yang meneliti tentang kontribusi lingkungan keluarga, keaktifan dan ketersediaan alat belajar terhadap motivasi berprestasi dan dampaknya pada hasil belajar matematika menyimpulkan bahwa terdapat pengaruh signifikan antara lingkungan keluarga, keaktifan, ketersediaan alat belajar dan motivasi berprestasi terhadap hasil belajar matematika. Rini Puspitasari (2013) yang meneliti tentang pengaruh kedisiplinan belajar dan lingkungan belajar terhadap hasil belajar matematika menyimpulkan bahwa terdapat pengaruh signifikan antara kedisiplinan belajar dan lingkungan belajar terhadap hasil belajar matematika.

Dalam penelitian ini, peneliti menggunakan kemampuan Kalkulus I dan Kalkulus II sebagai variabel penelitian yang mempengaruhi hasil belajar mata kuliah Analisis Vektor. Berdasarkan hasil analisis, diperoleh prosentase 
Kontribusi Kemampuan Kalkulus I dan Kalkulus II terhadap Hasil Belajar Mata Kuliah Analisis Vektor

sumbangan yang cukup tinggi diberikan oleh kemampuan Kalkulus I dan Kalkulus II terhadap hasil belajar mata kuliah Analisis Vektor, yaitu sebesar $75,1 \%$. Hal ini sesuai dengan hasil-hasil penelitian di atas yang menunjukkan bahwa selain kemampuan prasyarat, terdapat faktor-faktor lain yang mempengaruhi hasil belajar di antaranya fasilitas, motivasi, cara belajar/gaya belajar siswa, kreativitas siswa, lingkungan sekolah, tingkat pendidikan orang tua, lingkungan keluarga, keaktifan, ketersediaan alat belajar, kedisiplinan belajar dan lingkungan belajar. Faktor-faktor tersebut mungkin menjadi bagian dari $24,9 \%$ faktor-faktor yang memberikan kontribusi pada hasil belajar Analisis Vektor.

\section{Kesimpulan}

Berdasarkan pada tujuan penelitian dan analisis hasil penelitian yang telah diuraikan di atas, maka dapat ditarik kesimpulan sebagai berikut: (1) tidak ada kontribusi yang signifikan dari kemampuan Kalkulus I terhadap hasil belajar mata kuliah Analisis Vektor pada mahasiswa semester III Universitas Muhammadiyah Surakarta Tahun Ajaran 2014/2015, (2) ada kontribusi yang signifikan dari kemampuan Kalkulus II terhadap hasil belajar mata kuliah Analisis Vektor pada mahasiswa semester III Universitas Muhammadiyah Surakarta Tahun Ajaran 2014/2015, (3) ada kontribusi yang signifikan dari kemampuan Kalkulus I dan Kalkulus II terhadap hasil belajar mata kuliah Analisis Vektor pada mahasiswa semester III Universitas Muhammadiyah Surakarta Tahun Ajaran 2014/2015.

Kesimpulan penelitian di atas menunjukkan signifikansi pengaruh Kalkulus I dan Kalkulus II sebagai kemampuan prasyarat pada hasil belajar mahasiswa pada mata kuliah Analisis Vektor. Berlandaskan pada adanya pengaruh yang signifikan tersebut, maka perlu ditekankan tentang pentingnya kemampuan prasyarat untuk dikuasai mahasiswa secara tuntas sebelum mengambil mata kuliah Analisis Vektor. Oleh karena itu, ketika menempuh mata kuliah Kalkulus I dan Kalkulus II, dosen dan mahasiswa perlu memaksimalkan proses belajar untuk meningkatkan kemampuan 
mahasiswa sehingga dapat berdampak positif pada hasil belajar mahasiswa pada mata kuliah Analisis Vektor.

\section{Daftar Pustaka}

Djamarah, S. Bahri. 2008. Psikologi Belajar. Jakarta: PT Rineka Cipta.

Indonesia, T. R. K. B. B. 2005. Kamus besar bahasa Indonesia. Edisi ketiga. Cetakan ketiga. Jakarta: Pusat Pembinaan dan Pengembangan Bahasa Departemen Pendidikan Nasional RI dan Balai Pustaka.

Lestari, F. D. 2011. Pengaruh Motivasi Dan Cara Belajar Siswa Terhadap Prestasi Belajar Matematika (Pada Peserta Didik Kelas X SMA Negeri 2 Sragen Tahun Ajaran 2010/2011). Skripsi, Universitas Muhammadiyah Surakarta.

Maryadi, dkk. 2011. Pedoman Penulisan Skripsi FKIP. Surakarta: Badan Penerbit- FKIP Universitas Muhammadiyah Surakarta.

Paris, M. A., \& Assidiqi, H. 2014. Pengaruh Penguasaan Mahasiswa pada Mata Kuliah Prasyarat Terhadap Mata Kuliah Persamaan Diferensial Di Jurusan Pendidikan Matematika Tahun Akademik 2013/2014. Jurnal Pendidikan Matematika, 1(1).

Puspitasari, Rini. 2013. Pengaruh Kedisiplinan Belajar dan Lingkungan Belajar Terhadap Hasil Belajar Matematika Siswa Kelas VIII SMP N 2 Cawas TA 2012/2013. Skripsi. Universitas Muhammadiyah Surakarta.

Samino, Dkk. 2011. Layanan Bimbingan Belajar. Surakarta: Fairuz Media.

Septian, Ari. 2014. Pengaruh Kemampuan Prasyarat terhadap Kemampuan Penalaran Matematis dalam Matakuliah Analisis Real. ATIKAN: Jurnal Kajian Pendidikan, 4 (2), hal. 179-188. Bandung: Minda Masagi Press, FKIP UNSUR Cianjur, dan FPOK UPI Bandung.

Slamet Hw. 2007. Kalkulus 1. Surakarta: Muhammadiyah University Press.

Slamet Hw. 2003. Kalkulus 2. Surakarta: Muhammadiyah University Press.

Stewart, J. 2012. Calculus: early transcendentals. Belmont: Cengage Learning.

Sufren, Yoathan Nathael. 2014. Belajar Otodidak SPSS Pasti Bisa. Jakarta: Elex Media Komputindo. 
Kontribusi Kemampuan Kalkulus I dan Kalkulus II terhadap Hasil Belajar Mata Kuliah Analisis Vektor

Sugihartono, K. N. dkk. 2007. Psikologi Pendidikan. Yogyakarta: UNY Press.

Sugiono. 2009. Metode Penelitian Kuantitatif, Kualitatif dan R\&D. Bandung: Alfabeta.

Susilowati, Desi Eko. 2013. Kontribusi Lingkungan Keluarga, Keaktifan dan Ketersediaan Alat Belajar Terhadap Motivasi Berprestasi dan Dampaknya pada Hasil Belajar Matematika pada Siswa Kelas X Semester Gasal SMK Prawira Marta Kartasura TA 2012/2013. Skripsi. Universitas Muhammadiyah Surakarta.

Sutama. 2012. Metode Penelitian Pendidikan Kuantitatif, Kualitatif, PTK, $R \& D$. Surakarta: Fairuz Media.

Svinicki, M. 1994. What they don't know can hurt them: the role of prior knowledge in learning. Teaching excellence, 5(4), 1-2.

Varberg, D., Purcell, E. J., \& Steven, S. E. 2007. Calculus, 9th. New York: Pearson/Prentice Hall.

Sri Rejeki

Dosen Prodi PMTK, FKIP Universitas Muhamadiyah Suakarta

E-mail: Sri.Rejeki@ums.ac.id 
Sri Rejeki 